\title{
Primary School Students' Discipline through Scouting
}

\author{
M. Jaya Adi Putra ${ }^{1 *}$, Vera Hermaya ${ }^{1}$ \\ ${ }^{1}$ Faculty of Teacher Training and Education, University of Riau, Pekanbaru, Indonesia \\ jaya.adiputra@lecturer.unri.ac.id
}

Revised: February $10^{\text {th }}, 2020$

Accepted: February $16^{\text {th }}, 2020$

\begin{abstract}
The research aims to determine the discipline of students through scouting. This type of research is quantitative research with a correlational approach. The population used in this study were 81 Scouting students. Sampling using a saturated sampling technique. The instruments used in this study were scouting questionnaires. Data were analyzed using statistical analysis techniques, namely using the correlation test, significance test and test coefficient of determination. Based on the results of data processing it can be seen that student discipline is in a fairly good category with a percentage of $66.67 \%$ and scouting is in a fairly good category with a percentage of $66.67 \%$. Based on the results of testing the hypothesis it is known that the discipline of students through scouting is 0.398 . Based on the results of significant tests obtained t-test value of 3.853. Then based on the test results of the determinant coefficient there is the influence of the contribution among variables at $15.8 \%$. This means that there is a scouting contribution of $15.8 \%$ towards student discipline, while $84.2 \%$ is influenced by other factors not examined in this study.
\end{abstract}

Keywords: scouting; scouting students; student discipline.

\section{INTRODUCTION}

Scouting education is a process of education that is practically outside of the school field and outside the family environment carried out in the open in the form of interesting, challenging, fun, healthy, organized and directed activities by applying Scouting Principles and Scouting Methods whose ultimate goal is the formation of character, personality and noble character. The Basic Principle of Scouting is the principle that underlies scouting activities in an effort to foster the character of students. This can be seen in obedience to the honor code (Basic Principle of Honor) and the practice of honor codes (Scouting Method). The scouting movement is a non-formal educational, organisation, which is defined by the United Nations Educational Scintifict and Cultural Organization (UNESCO) as having organised educational activity outside the estabilished formal system, that is intended to deliver a defined set of learning objectives to an identifiables group of learnes (Liem, 2014). Scouting was chosen as a comprative educational 
model for several reason. fisrt of all, it is a well-structured educational method that is a spread worldwide and that uses an active learning approach in order to develop moral values and ledership attitude in young people (du Merac, 2015).

Scouting education in schools is a nonformal education which is a forum for implementing education on coherence carried out in Indonesia aimed at forming characters that are adapted to the values of the Scout Dasa as a fear of God Almighty; Love for nature and affection to us fellow human; polite patriots and knights; obedient and like to discuss; willing to help and steadfast; diligent, skilled and happy; economical, meticulous and simple; discipline, courage, and loyalty; responsible and trustworthy; holy in thoughts, words and deeds. Then it will indirectly affect the discipline of students. The same opinion expressed by (Kurniasih, 2014) namely with the presence of scouting extracurricular activities in schools can train and grow or shape discipline.

Someone is said to be disciplined when doing activities in an orderly and orderly manner in accordance with the time and place and done with full awareness, perseverance, sincerity or without coercion from any party. One characteristic of scouting activities is the problem of time discipline. Every scouting activity always starts on time, starting from the accuracy of entering and returning to school and the accuracy in doing the assignments given. Not only disciplined with time, there is also discipline in using attributes and even obeying the teacher's orders.

The formulation of the problem in this study is whether there is a relationship between students' discipline through scouting. And the purpose of this study is to find out is there a relationship between students' discipline through scouting.

\section{METHODS}

This research was conducted in Pekanbaru City, Riau Province, Indonesia. This research is included in the type of quantitative research. The type of this research is correlation. Correlation research is research conducted by researchers to determine the level of relations between two or more variables, without making changes, additions or manipulations of data that already exists (Arikunto, 2010), and to find out the relationship between student discipline through scouting. The population used in this study were 81 Scouting Scout students. The sampling technique in this study was Saturated Sampling. The instrument used in this study was a questionnaire. The data analysis technique in this study is quantitative/statistical.

\section{RESULTS}

Data collection techniques in this study were conducted by distributing questionnaires. Questionnaire used in the form of a statement using a Likert scale. then the research instrument was carried out by validity and reliability testing. The validity test used in this study uses the 
test of construct validity (judgment experts) and content validity through a questionnaire trial. Next, test the reliability of the research instruments. After conducting a validity test that produces a validated research instrument, the research is conducted by distributing validated research instruments in the form of questionnaires. The next step is analyzing the data that has been obtained from the respondents by testing the data analysis prerequisites, namely through the normality test and linearity test. Then by testing the hypothesis through the correlation coefficient test, the significance test and the coefficient of determination. After the data analysis is complete, the results of the study can be concluded:

\section{Description of Student Discipline and Scouting}

a. Description of Student Discipline Data

Data variables of student discipline were measured using research instruments in the form of questionnaires, namely student discipline questionnaire based on indicator by Hidayat's (2013) which consisted of (1) the accuracy of school entry and return, (2) accuracy in using clothing and school attributes, (3) accuracy in working school assignments, (4) compliance with teacher orders. Scouting skills questionnaire consists of 26 statements with likert scale answer choices. The results of data collection through questionnaires, then tabulated and calculated the number of scores. The lowest score obtained in this study was 60 and the highest score in this study was 95 . In the disciplinary variables students obtained mean (M) of 78.23 and standard deviation (SD) of 7.63. The classification of student discipline data is as follows:

Table 1. Classification of Student Discipline Data

\begin{tabular}{|c|c|c|c|c|c|}
\hline \multicolumn{3}{|c|}{ Interval } & Category & Frequency & Percentage \\
\hline \multirow{3}{*}{71} & $x \geq$ & 86 & Good & 13 & $16,05 \%$ \\
\hline & $\leq x<$ & 86 & Fairly Good & 54 & $66,67 \%$ \\
\hline & $x<$ & 71 & les & 14 & $17,28 \%$ \\
\hline \multicolumn{4}{|c|}{ Total } & 81 & $100 \%$ \\
\hline
\end{tabular}

Based on table 1, it can be seen the discipline of students for the good category frequency of 13 students with a percentage of $16.05 \%$, for the fairly good category the frequency is 54 students with a percentage of $66.67 \%$, and for the less frequent category 14 students with a percentage of $17.28 \%$. This shows that student discipline is in a fairly good category.

b. Description of Scouting Data

Scouting variables were measured using scouting questionnaire instruments based on indicators according to Jana $\mathrm{T}$. 
Anggadiredja (2011) which consisted of (1) developing spiritual aspects, (2) developing emotional aspects, developing social aspects, (4) developing intellectual aspects, (5) development of physical aspects. Scouting skills questionnaire consists of 25 item statements with answer choices using a Likert scale. The results of data retrieval through questionnaires are then tabulated and the total score is calculated. The lowest score obtained in this study was 43 and the highest score in this study was 83 . In the scouting skill variable the mean (M) was 64.23 , the standard deviation (SD) was 8.75. The classification of scouting data is as follows:

Table 2. Classification of Scouting Data

\begin{tabular}{|c|c|c|c|c|c|}
\hline \multicolumn{3}{|c|}{ Interval } & Category & Frequency & Percentage \\
\hline & $x \geq$ & 73 & Good & 12 & $14,81 \%$ \\
\hline \multirow[t]{3}{*}{55} & $\leq x<$ & 73 & Fairly Good & 54 & $66,67 \%$ \\
\hline & $x<$ & 55 & Less & 15 & $18,52 \%$ \\
\hline & \multicolumn{3}{|c|}{ Total } & 81 & $100 \%$ \\
\hline
\end{tabular}

Prerequisite Test for Data Analysis

a. Normality test

Normality testing is done to determine the normality of a data distribution or not. The normality test was used through the SPSS version 23 program with the
Kolmogrof-smirnov formula with a significance level of 5\%. Data distribution is said to be normal if a significant value is greater than 0.05 (Sig $>0.05$ ) (Gunawan, 2013).

Table 3. Test Results for Normality of Discipline of Students with Scouting Kolmogorov-Smirnov ${ }^{a}$

\begin{tabular}{lccc} 
& Statistic & Df & Sig. \\
\hline Students Discipline $(\mathrm{X})$ & 0.070 & 81 & $0.200^{*}$ \\
Scouting $(\mathrm{Y})$ & 0.061 & 81 & $0.200^{*}$
\end{tabular}

Based on table 3, the normality test on student discipline variables obtained a significance value of $(0.200>0.05)$ and the scouting variable obtained a significance value of $0.200 \quad(0.200>$ 0.05). Based on the results of these calculations, the data on student discipline variables (Variable $\mathrm{X}$ ) and scouting data (Variable $Y$ ) can be concluded to be normally distributed. 
b. Linearity Test

Table 4. Linearity Test for Discipline Students through Scouting

\begin{tabular}{|c|c|c|c|c|c|c|c|}
\hline & & & $\begin{array}{l}\text { Sum of } \\
\text { Squares }\end{array}$ & df & $\begin{array}{l}\text { Mean } \\
\text { Square }\end{array}$ & $\mathrm{F}$ & Sig. \\
\hline \multirow{4}{*}{$\begin{array}{l}\text { Scoting }(Y) \\
* \text { Student Disc } \\
\text { ipline }(X)\end{array}$} & Between & (Combined) & 1956.57 & 33 & 59.29 & 1.03 & 0.45 \\
\hline & \multirow[t]{2}{*}{ Groups } & Linearity & 736.53 & 1 & 736.53 & 12.82 & 0.001 \\
\hline & & $\begin{array}{l}\text { Deviation } \\
\text { from Linearity }\end{array}$ & 1220.05 & 32 & 38.1 .3 & 0.66 & 0.88 \\
\hline & \multicolumn{2}{|c|}{ Within Groups } & $\begin{array}{l}2699.97 \\
4656.54\end{array}$ & $\begin{array}{l}47 \\
80\end{array}$ & 57.45 & & \\
\hline
\end{tabular}

Based on data from table 4, it can be seen that the significance of the Deviation From Linearity is 0.888 . This means that this value is greater than $0.005(0.888>0.05)$. Thus it can be concluded that the relationship between student discipline through scouting has a linear relationship.

c. Hypothesis testing

Product Moment Correlation Test

Table 5. Test Results Correlation of Student Discipline through Scouting

\begin{tabular}{|c|c|c|c|}
\hline \multirow{4}{*}{ Student Discipline (X) } & & Student Discipline (X) & Scouting $(Y)$ \\
\hline & $\begin{array}{l}\text { Pearson } \\
\text { Correlation }\end{array}$ & 1 & $0.398^{* *}$ \\
\hline & Sig. (2-tailed) & & 0.000 \\
\hline & $\mathrm{N}$ & 81 & 81 \\
\hline \multirow[t]{2}{*}{ Scouting $(Y)$} & $\begin{array}{l}\text { Pearson } \\
\text { Correlation }\end{array}$ & $0.398^{* *}$ & 1 \\
\hline & $\begin{array}{l}\text { Sig. (2-tailed) } \\
\mathrm{N}\end{array}$ & $\begin{array}{r}0.000 \\
81\end{array}$ & 81 \\
\hline
\end{tabular}

Based on table 5 . the results of the data obtained by the value of r-count 0.398 , which means the relationship between student discipline through scouting is equal to 0.398 . From the results of the correlation output in the Correlation table the significance of 0,000 is generated, when compared with 0.5 the value of Significance is smaller $(0,000<0,05)$. This means that there is a significant relationship between student discipline through scouting. Because the correlation coefficient is positive, it means that student discipline is positively related (unidirectional) and significance to scouting. 
Significance Test

Table 6. Results of Significance Tests for Discipline of Students with Scouting

\begin{tabular}{lccc}
\hline Student Discipline & t-test & t-table & Information \\
\cline { 2 - 4 } through Scouting & 3,853 & 1,990 & There is correlation
\end{tabular}

Based on table 6 , shows the results of the calculation of students' disciplinary significance through scouting, namely ttest 3.853 and $t$-table for the $5 \%$ error rate of the two-party test where $\mathrm{dk}=\mathrm{n}-2$ $(81-2=79)$ which is equal to 1,990 . Shows that t-test is 3.853> t-table 1.990 (t-test> t-table. This means that there is a significant relationship between student discipline through scouting.
Coefficient of Determination

The determinant coefficient test is used to state the size of the contribution of variable $\mathrm{X}$ to variable $\mathrm{Y}$. Based on the test results of the coefficient of determination there is an influence between student discipline through scouting.

Table 7. Coefficient Determination Test Results on Student Discipline

\begin{tabular}{lccc}
\hline $\begin{array}{l}\text { Student } \\
\text { through Scouting }\end{array}$ & \begin{tabular}{c} 
Discipline \\
\cline { 2 - 4 }
\end{tabular} & $\begin{array}{c}\mathrm{R} \\
\text { Square }\end{array}$ & Determinant coefficient \\
\cline { 2 - 4 } & 0.398 & 0.158 & $15,8 \%$ \\
\hline
\end{tabular}

Based on the data in table 4.7, the test results of the determinant coefficient have the effect of a contribution between variables of $15.8 \%$. This means that there is a scouting contribution of $15.8 \%$ towards student discipline and $84.2 \%$ is influenced by other factors not examined.

\section{DISCUSSION}

Based on the results of the data analysis above, it can be seen that student discipline of $66.67 \%$ which is included in the category is quite good, and scouting of $66.67 \%$ which is included in the fairly good category. Then based on the results of data analysis, the correlation between students' discipline through scouting is known to be 0.398 which is in a positive direction, meaning that more positive exposure will be followed by high student discipline, and vice versa the more negative scouting will be followed by low student discipline.

In this study, researchers previously hypothesized that there was a significant relationship between students' discipline through scouting, because one of the characteristics of scouting activities was a matter of time discipline. Every scouting activity always starts on time, starting from the accuracy of entering and returning to school and the accuracy in doing the assignments given. Not only 
disciplined with time, there is also discipline in using attributes and even obeying the teacher's orders.

After conducting research, researchers found a significant relationship between student discipline through scouting, this was evidenced by the results of the correlation test using SPSS version 23 computer program, based on the results obtained by the value of 0.398 which means the relationship between student discipline through scouting is 0.398 . Based on the significance test of the ttest value of 3.853 and $t$-table for the $5 \%$ error rate the two-party test where $\mathrm{dk}=\mathrm{n}-2(81-2=79)$ is equal to 1,990 . It shows that t-test is $3.853>$ t-table 1.990 (t-test> t-table. This means that there is a significant relationship between student discipline through scouting. Then based on the test results of determinant coefficients there is a contribution of $15.8 \%$ among variables. scouting contributions of $15.8 \%$ towards student discipline, while $84.2 \%$ was influenced by other factors not examined in this study.

\section{CONCLUSION}

Based on research on student discipline through scouting, it can be concluded that:

1. There is a relationship between student discipline through scouting which is equal to 0.398 .

2. There is a significant relationship between student discipline through scouting, which is 3,853 .

3. Scouting contributes $15.8 \%$ to student discipline, while $84.2 \%$ is influenced by other factors not examined in this study.

\section{REFERENCES}

Arikunto, S. (2010). Pengantar Statistik Pendidikan. Bandung: Gravindo.

du Merac, E. R. (2015). What We know about the Impact of School and Scouting on Adolescents' Valuebased Leadership. ECPS Journal. (Online). $11: 208$. https://scholar.google.co.id/scholar? $\mathrm{hl}=\mathrm{id} \& a s_{\text {_sdt }}=0 \% 2 \mathrm{C} 5 \& \mathrm{q}=$ what + we+ know+about+the+impact+of+school +and+scouting\&btn $\mathrm{G}=\# \mathrm{~d}=\mathrm{gs}$ _qabs $\left.\% d u=\% 23 p \% 3 D E \_4 g j B w B 12 g\right]$ (diakses pada tanggal 23 Juli 2019) Gunawan, M. A. (2013). Statistik untuk Penelitian Pendidikan. Yogyakarta: Parama Publishing.

Hidayat, H. S. (2013). Pengaruh Kerjasama Oranng Tua Dan Guru Terhadap Disiplin Peserta Didik Di Sekolah Menengah Pertama (SMP) Negeri Kecamatan Jagakarsa- Jakarta Selatan. Jurnal IImiah WIDYA, 93. (Online)

https://scholar.google.co.id/scholar? $\mathrm{hl}=\mathrm{id} \& a s \_s d t=0 \% 2 \mathrm{C} 5 \& \mathrm{q}=$ non + form al+education $\% 3 \mathrm{~A}+$ scouting $\% 2 \mathrm{C}+\mathrm{sch}$ ooling+and+teacher+\&btnG =\#d=gs qabs\&u=\%23p\%3DPcP3vsJ3m7EJ

Jana T., \& Anggadiredja, A. D. (2011). Syarat Kecakapan Umum Penggalang. Jakarta: Kwartir Nasional Gerakan Pramuka.

Kurniasih, S. B. (2014). Implementasi Kurikulum 2013 Konsep dan Penerapan. Yogyakarta: Kata Pena. 

(Online) 